\title{
Sufism: Origin and Basic Concepts
}

Dr Syed Damsaz Ali Andrabi (Corresponding author)

Higher Education Department Jammu and Kashmir

Govt. Degree College Boys Pulwama, Kashmir

Tel: 96-2264-0951Ｅ-mail: damsaz.andrabi@gmail.com

Received: May 9, 2015 Accepted: May 12, 2015 Published: May 13, 2015

doi:10.5296/ijch.v2i1.7597 URL: http://dx.doi.org/10.5296/ijch.v2i1.7597

\begin{abstract}
Sufism is a highly developed system based on process of thought and action which demands absolute love towards God and service to humanity. The Sufism has a deep influence on the varied populations of the world. The carriers of the Sufism were the Sufis and they have removed all the possible barriers and obstacles among different sections of people. Their message was unity and love. Every possible effort was made by them to spread the education among people. Because education and unity are itself a way towards progress. People were encouraged and advised by them to adopt different economic activities. Structural changes were brought by the Sufis in the society.
\end{abstract}

Keywords: Equality, Unity, Love, Honesty, Development, Innovations, Change, Service and etc.

\section{Introduction}

The mystical side of Islam is called Sufism ${ }^{1}$, which is a part of the religion. It is the purification of the heart from the recurrence of worldly temptations ${ }^{2}$. Its basic idea is to make one adhere to spiritual values to ascend by means of divine knowledge, to be occupied with that which is eternally the best to all people irrespective of creed, to seek the truth. The means of Sufism is to gain knowledge through observation, experimentation and verification, so that we can distinguish between absolute and reality. As God is absolute, we can not know any thing about him. Sufism is highly developed system based on process of thought and action which demands passionate love towards God and sincere service to humanity. Sufis attach much importance to the love of Almighty, and their only concern is to be lost in the ocean of love. They believe that the whole of universe is truly a mirror of God, that there is only one perfect beauty and that is $\operatorname{God}^{3}$. They hold that if men wish to move near of God, they must seek him in the hearts of men. It were the Sufis who carried teachings to the deprived ranks of the people and provided emotional rationalism for self purification and valuable social 
services were provided to the people. Much has been said by the Muslim scholars of Sufism ${ }^{4}$ on the derivations of the word Sufi. Different opinions were put forward and its derivation was sought by some from Safa (purity), Ashab-i-Suffa (peoples of the bench) and even from the Greek word Sophia (wisdom).Some masters even suggested that Sufi, in earlier times was one who can read and write the Quran. Now generally it is recognized that the term Sufism has been derived from Suf, which means coarse wool, signifying a hard and simple life. The word Sufi itself came into use before the second century Hijri which corresponds to (822.A.D). All Sufis agree that all the ordinances imposed by God on his servants in his holy book and all the injunctions laid down by the Prophet in his traditions upon the believers are in nature of mandates, which have to obey by all. It is in that sense that Sufism is purely an Islamic discipline. Even in the life time of Prophet ${ }^{5}$, some of his followers wished to enter into close relationship with God by slackening their attachment to this material and temporary world. The basic concept of Sufism is living a way of life like Prophet Mohammad related to the fundamental contents of Islam. Sufis are pious trying to follow the path of Prophet Mohammad ${ }^{6}$, like the rest of believers, differentiating persons only in respect of sincerity, piety, love and fear of God and their zeal in following the Prophet Mohammad in conduct. Sufis ${ }^{7}$ like the companions of the Prophet who submitted themselves to the word of God and followed the way of Prophet Mohammad in all their actions, their ideas and in any problems relating to their social and religious life. The companions were better known by the distinguished title Sahaba, the first generation of the Prophet Mohammad, Tabi'un the second generation and the third generation was called as Taba, Tabi'un. Prophet Mohammad himself has declared the best of the times was my time and then the one that succeeds it and then the one that succeeded. He said my companions are like stars, which ever of them you follow you will be on the right path and exhorted his companions when he said that my companions are the best of men. The companions ${ }^{8}$ of the Prophet Mohammad have a special place of honour in the lives of every Muslim and in particular the Sufis.

The Sufis are not an ethnic or religious group, but a mystical movement that is found all over the Islamic world and that still has a deep influence on the varied populations of the world. Sufism $^{9}$ grew historically as a reaction against the rigid legalism of the orthodox religious leadership and as a counterweight to the growing worldliness of the expanding Muslim empire. One source of Sufism is to be found in the twofold presentation of $\operatorname{God}^{10}$ in the Quran.

Prophet Mohammad ${ }^{11}$ is regarded as the true spiritual guide on the ascetic path and later Sufis considered him to be an ideal from all spiritual aspects. No person on this earth could be compared to Prophet Mohammad. He is the chosen ideal and messenger of God. He constantly reminded the people to prepare themselves for the heavenly life in accordance with the teachings of the Holy Quran. The life of the present is nothing but temporary enjoyment. It is the hereafter that is the home. He had the good and far better qualities, lived a life of perfect solitude in meditation and prayer. He is the embodiment of the teachings of the Quran ${ }^{12}$ for his entire life in confronting with the teachings of the Holy Quran. He taught the people to submit totally of their will to the will of God. The Sufis regard love of God as the sole means of reaching their goal. They enjoy the nearness of God in direct communion with the divine. The Sufis believe that the intimate ${ }^{13}$ experience of the divine helps them to 
keep away from the phenonimial world of corruption, arrogance, revenge and inequality. That is why we can say that Sufism ${ }^{14}$ is a way towards the reality and godly qualities. Long hours of prayers, physical mortification and sacrifice of the Prophet remained as example to thousands of ardent and sincere Sufis of later generation. There are three essential features of Tasawuf ${ }^{15}$, which are, tenacious attachment to poverty and indigence a profound sense of sacrifice and renunciation and absence of self obtrusion and personal violation. Our earthly life is transitory; we are pilgrims on the earth, only $\mathrm{God}^{16}$ is eternal. The world is like snow exposed to the sun, which continues to melt until it disappears altogether, while the next life is like a precious stone ${ }^{17}$ which never melts away. Sufism enlightens people to realize this fact of life and shows the path to live accordingly.

A brief account of the basic features, concepts and terminology specific to Sufism. Most of them are common across various Sufi Silsilas.

Wahdatal Shuhud: Unity in experience, implying that Allah and his seeker are joined together, and their individuality is preserved. In this type of unity the seeker is well aware not only of his human individuality but more importantly of his lords unique individuality.

Wahdatal Wujud: Identification of God with natural objects e.g., sunset, sunrise, greenery, the starry sky, the sun, the moon, the mountains and in the heart of human beings. The nature of this unity can be clearly understood within the deeper spiritual framework of the Quran and the Sunnah. The most adherents of the Wahdatal Wujud believed that everything is Almighty. Sufis recognise both the immanence and the transcendence of God at one and the same time.

\section{Main Characteristic Features of Sufism}

Tariqat: The Quran says obey God and the Prophet in letter and spirit and obey those amongst you who hold the command. Therefore it is very essential that Sufi must first discipline his mind by living according to prescribed law and must observe and fulfill all religious obligations, such as Prayer, Fasting, Tawhid, Zakat and Pilgrimage to Mecca. When his mind and body is fully trained to obey, serve and to respect, he then passes to the second stage named as Tariqat ${ }^{18}$, the path in addition to religious observances, he is supposed to seek spiritual guide and totally remain under his care. The spiritual guide called Pir in Iranian and Sheikh in Arabic and to receive instructions from him on conduct, control over passions and to purify the inner soul. When he is admitted by his spiritual master into a Sufi order, he must observe its rules, such as service, humility, vigils of every kind, occasional fasts as directed by his Pir, collection of alms for the maintenance of Khanqah and Sufi assemblies. As a beginner he must obey all directions of his Pir without any argument, to the extent of annihilating his will and judgment by merging it in the will of his Pir, this then will be called as annihilation in the Sheikh. When the beginner has observed all the rules of Tariqat as are mandatory to the satisfaction of his Pir, he then is given the Sufi garment called Khirqa.

Haqiqat: Is recognized as the next higher stage for the attainment of truth and knowledge. The aim of the Sufi $^{19}$ is self-purification and union with the God, which cannot be gained by self-endeavor. It is a divine gift and granted to whomsoever God is pleased with after passing different crucial stages. To gain and achieve the goal entirely depends upon his mercy. Man's 
duty is to serve God, till mercy is shown to him. A Sufi is supposed to purify his heart first only then he can realize the ultimate reality the truth of truths. All human actions should be according to the will of divine being. It is only through self-discipline, devotion, virtue and intention that one can recognize his God, such a stage is called annihilation in God.

Marifat: Marifat in Sufi terminology means the mystical knowledge of God. In this stage it is believed that the Sufi has realized the truth and his heart is full of wisdom. The Marifat leads to the ultimate love of God and the highest degree of gnosis leads to the perfect love of God. The love of God is the ultimate end of the life and those who do not believe in this are imperfect ones. All the Sufis have accepted love as the ideal relationship between God and man. As the love based on spiritual relationship has no worldly source. There are many ways of infusing love into man and combine it in their highest perfection with God. The man's love for God is the result of Marifat.

Tawakul: Tawakul (trust in God) demands that the traveler on the spiritual path should entrust himself in all ways and works to God in a spirit of complete submission. Even some extremists went to the extent of neither working nor even begging and of expecting that their daily necessities would reach them without laboring to obtain them. Such an idea led to quietism and degenerated into laziness and inertia. But instead of laziness the principle of Tawakul was also preferred by a well known Sufi of his times namely Shaqiq of Balkh, (d.810.A.D) belonged to trading community and for this purpose he moved to Turkistan. There he came into contact with some idol worshippers and that interaction was a turning point in his life. Now he got inclined towards asceticism and got settled in Khurasan. The principle of Tawakul ${ }^{20}$ was preferred by him .He once remarked that the efforts put in by man in seeking livelihood are the result of his ignorance of God's ways of dealing with men and therefore to work hard in order to win bread is unlawful. But in contrast to this particular statement there is another statement of Ibrahim (d.777.A.D) also known by the name of second Junaid (d.910.A.D) of Baghdad. For him the true and real Sufi is one who covets nothing of this world, nothing of the next and devotes himself exclusively to $\mathrm{God}^{21}$. The celibacy and poverty was advocated by him as the pre requisites of the asceticism. When a Sufi marries he enters, so to say a boat, when he gets a child, his boat sinks and his asceticism disappears. The principle of Tawakul was preferred, but in his case it was a moral principle as enunciated in the Quran, which does not exclude earning one's livelihood by one's own efforts.

Hal: Hal or condition is a mental state gifted momentarily by divine grace. After different hardships spiritual food is granted and expanded in his favour. When it is gifted continuously, it is called possession and when it becomes everlasting it is named as Muqam or station. Regarding the different stages viz, Hal and Muqam a well-known Sufi advisor namely Muhasibi has provided the valuable piece of information. The Sufism enters into its second important stage of development during the time of Muhasibi ${ }^{22}$ (d.857.A.D) and gave it a theoretical basis. The important contribution of Muhasibi ${ }^{23}$ to the science of mysticism is his definition of station and the state (hal), and his inclusion of satisfaction (rida). Station according to him is the particular position which a seeker attains after making necessary efforts to reach it. State on the other hand is something that man receives through God's 
grace without involving effort on his part. The station in short belongs to the category of acts, while state belongs to the category of gifts. With regards to the problem whether an attitude of poverty or wealth is preferable for a mystic. Muhasibi holds that latter attitude is better. He argues that wealth ${ }^{24}$ is an attribute of God, whereas poverty cannot be ascribed to him and therefore an attribute common to God and man is superior to an attribute that is not applicable to God. Similarly controversy as to whether presence or absence is preferable for the mystic is that presence is superior to absence, from one's self is a primary stage on the mystic path, which gradually leads to presence before God.

Zikr: The remembrance of the lord's name is known as $\mathrm{Zikr}^{25}$. The literal meaning of which is recollection is used by the Sufis especially for remembrance of God. Zikr is conscious recollection of God to the exclusion of all that is other than God. The following twenty manners must be observed by the performer with regard to Zikr. Five of them are due before the commencement of Zikr, tweleve during Zikr and the remaining three must be observed after the Zikr session is over. The preliminary five manners are: to perform bath and abulution, taub-wa-Istighfa, observing silence maintaining atmosphere of tranquility and composure, reposing complete confidence in Murshid (spiritual master) that help will reach in through his intermediation and at the same time holding this firm belief that real intermediary in this behalf is the holy Prophet Mohammad. The twelve manners to be observed during Zikr are facing the direction of Qiblah and sitting in the posture as in prayer, placing both hands on thighs keeping the eyes close, keeping body clean, sitting in dark room, holding firm belief that the objective for which Zikr is undertaken shall be realized, asserting sincerity of intention and making heart free from all apprehension and perilous thoughts. Embodying the concept of Murshid in the heart so firmly that not a single moment is spent without thought of him and the last three measures of Zikr are, keeping calm and silent in comfort and ease. The Sufi spiritual masters have divided the Zikr into different categories, Nasooti Zikr of tongue-Malkooti (Zikr of heart), Jabrooti (Zikr of spirit) and Lahooti Zikr of mind. The remembrance of the sacred word is required to be uttered in a suitable way but in all cases, it should be co joined with the life of breath. If it is audible the invocation is done through tongue in a loud voice. If you hum the sacred word, it is a Zikr of the heart. A stage comes when you go deeper into a Zikr and it becomes Zikri Jabrooti .The final and last stage when a seeker merges with the divine, the Zikr becomes a part of the high consciousness.

Chillah: Sufis believe that the best way to perform the practice of Chillah ${ }^{26}$ is to observe fast during day time as fasting is always beneficial to control temptations and desires. Continuous fasting without any break is the most effective remedy followed by night vigil should remain continuous practice and over oversleeping should be avoided, because without night vigil no Salik (Sufi traveler) can attain his goal. The Salik should cultivate practice of prayers most frequently as prayer is instrumental to spiritual elevation. Indeed Allah loves those who purify themselves and Wadu considered as an effective way of purification. The place for seclusion should be narrow with only one opening door and there should be no outside disturbance of sounds and voices which detract the devotion. The door should be kept closed all the time so as to obstruct the incoming light. In case the Salik finds no place from outside interference, he should keep his ears stuffed with flakes of cotton and eyes close at the time 
he is engaged in remembrance. The duration of a Chillah (normally a period of forty days) still will be decided by Murshid and the Murid will have to follow the instructions with care. The basic objective behind Chillah is to purify the Murids heart from internal pollutions. One should enter into Khalwat leaving aside all worldly desires so that he may see hidden things with his inward eye. One should show complete respect and love for his creator coupled with full of patience to win divine pleasure till the last breath.

Sama: The Sama means listening to the Sufi poetry for the enlightenment of soul. For Sufis Sama is an act of devotion, devised to draw the attention of God. A Sufi must train his mind to appreciate beauty and by some means to stir his inner spiritual feeling and music is considered to be beauty and harmony in sound. Some Sufi Silsilas permit the $\mathrm{Sama}^{27}$ in which music is played, songs are sung. The said music acts as a way of bringing illumination into one's consciousness. Even the labourers, peasants, shepherds, boatmen and any kind of manual workers forget the boredom of their toil while they sing or listen music because every music has its appeal. When music has such a profound impact on human's beings as well as on birds and animals and when it stirs up emotions and feelings in the hearts of almost all listeners, why should it fail to arouse the feeling of devotion and ecstasy in the hearts which are inebriated with the love of God. Even Sama has been supported and practised by the innumerable Sufis and was in vogue throughout the Muslim world and at present is practised at a number of places especially in India.

\section{Conclusion}

The Sufis dispersed to various parts with an avowed objective to make people understand the concept of divine unity. According to their philosophy the source of love is from the Qalb (Heart). The only message of Sufism is unity and love. It implies that the truth is attained when aspirant abandons his lower self (nafs) and develops his pure self. Pure self is a mirror which reveals the glory to God. All the Sufis were of the opinion that Muslims should limit their desires according to the principles of Islam. They also stressed on social justice, which is considered to be the core of social stability.

\section{Notes and References}

1. Kamal Mir, Inshai Mir Kamal, Mss, pp. 24, Research library University of Kashmir.

2. Hussain Qadri M, Fatuhati Qadriya, Mss, pp. 208, Research library University of Kashmir.

3. Miskin Mohiu'd-din, Tarikhi Kabir, Srinagar, 1905, pp. 31, 33.

4. Ahmad Zuharu'd-din, Mystic Tendencies in Islam, Delhi, 1999, pp.10.

5. Sabur Ahmad Ibni, Khawariqus Salikeen, Mss. pp. 95, Research library University of Kashmir.

6. Ahmad Syed, Tohfa Syed, Mss, pp, 10-11, Research library University of Kashmir.

7. S. J., Lamens, Islam Beliefs and Institutions, New Delhi, 1979, pp. 15. 
8. Ali K., A Study of Islamic History, Delhi, 1980, pp. 80, 342.

9. Danner Jabbar A, The Islamic Tradition, New Delhi, 2004, pp. 121.

10. Gamgeen Shams'd-din, Nazneen Gamgeen, Srinagar, 1985, pp. 110-11.

11. Ahmad Zuhuru'd-din, Mystic Tendencies in Islam, Delhi, 1999, pp. 31-32.

12. Gamgeen Shams'd-din, Bahar Seerat Gamgeen, Srinagar, 1998, pp. 21.

13. Dhar A, N, Mysticism across Cultures, New Delhi, 2002, pp. 5-6.

14. Ahmad Shamsu-d-din, Shasmsul Tawarikh, Srinagar, 2003, pp. 410-11.

15. Ali K., A Study of Islamic History, Delhi, 1980, pp. 80, 342.

16. Danner Jabbar A, The Islamic Tradition, New Delhi, 2004, pp. 121.

17. Gamgeen Shams'd-din, Nazneen Gamgeen, Srinagar, 1985, pp. 112-113.

18. Huges, Outlines Of Islam, vol, 2, New Delhi, 1998, pp. 377.

19. Sheikh Karim A., Muslim's Character, Delhi, 1983, pp. 71.

20. Fazl Abul M., Selection from the Quran, vol, iv, New Delhi, 1998, pp. 45.

21. Khan Shabir M., Social Structure and Economic Change in Islam, Aligarh, 1987, pp. 6-7.

22. Ali Ameer S., The Spirit of Islam, Delhi, 1981, pp. 414.

23. Stern M., Al-Ghazali on Repentance, New Delhi, 1990, pp. 10.

24. Rahman Afzal, Subject Index of the Holy Quran, New Delhi, 1992, pp. 85.

25. Atiyeh George N., Al-Kindi, The Philosophy of the Arabs, New Delhi, 1994, pp. 88.

26. Huges, Outlines of Islam, vol, 2, New Delhi, 1998, pp. 142-43.

27. Hussain F. M, Mystical Ecstasy, Sufi Practices, Srinagar, 2007, pp. 51-52.

\section{Copyright Disclaimer}

Copyright for this article is retained by the author(s), with first publication rights granted to the journal.

This is an open-access article distributed under the terms and conditions of the Creative Commons Attribution license (http://creativecommons.org/licenses/by/3.0/). 